\title{
Multilevel Inverters for Grid Connected Photovoltaic System
}

\author{
Mary George ${ }^{1}$, Anil kumar V M ${ }^{2}$ \\ ${ }^{1}$ (Power Electronics and Control, Government Engineering College Idukki, India) \\ 2 (Asst. Professor, Electrical and Electronics Engineering, Government Engineering College Idukki, India)
}

\begin{abstract}
In this paper two multilevel inverter topologies, a single phase five level inverter and a seven level inverter which is suitable for interfacing a photovoltaic system to the grid is presented. The multilevel inverter uses a Pulse Width Modulation scheme using two reference signals for five level inverter and three reference signals for seven level inverters. The reference signals are identical to each other with an offset equivalent to the amplitude of the carrier signal. A PI controller is used to keep the current injected into the grid sinusoidal and also to keep the DC link voltage constant under varying atmospheric conditions. The multilevel inverter offers much less total harmonic distortion compared to the conventional $H$-bridge inverter. This is verified through simulation using MATLAB/SIMULINK.
\end{abstract}

Keywords: Grid connected, Photovoltaic, Proportional-Integral current control, PWM inverter

\section{INTRODUCTION}

The conventional energy sources are fast depleting these days. So the demand for renewable energy sources has been increased. Among the renewable energy sources photovoltaic systems can be considered as a very good source of energy because of its consistency and cleanliness. The power developed by photovoltaic system is DC. To convert this DC power a photovoltaic inverter is used. Improving the output waveform of the inverter helps to reduce the harmonic content in the current injected into the grid in a grid connected system. For this a five level inverter is considered here. Such multilevel inverters helps to reduce the electromagnetic interference and also in reducing the filter size.

\section{MODELING OF PV MODULE}

The basic unit of a PV module is the solar cell, which consists of a p-n junction that converts light energy directly into electrical energy. The equivalent circuit of a solar cell is shown in Fig.1



Fig.1 Equivalent circuit of solar cell

Here Ig is the light generated current, Id is the diode current, Rsh is the shunt resistance which describes the leakage current, Rs is the series resistance which describes the voltage drop as the charge carriers migrate from the $\mathrm{p}-\mathrm{n}$ junction to the electrical contacts.

A number of PV cells are connected together so as to form PV modules and PV arrays. The mathematical model for simulating PV modules or arrays consists of the following equations.

$$
I=n_{p} I_{g}-n_{p} I_{r s}\left[\exp \left(\frac{q}{k T A} \frac{V}{n_{s}}\right)-1\right]
$$

where I is the PV array output current; $\mathrm{n}_{\mathrm{p}}$ is the number of solar cells connected in parallel; $\mathrm{I}_{\mathrm{g}}$ is the light generated current also called insolation current; $I_{\mathrm{rs}}$ is the reverse saturation current; $q$ is the charge of the electron; $\mathrm{k}$ is the Boltzman's constant; $\mathrm{T}$ is the cell temperature in Kelvin; $\mathrm{A}$ is the ideality factor; $\mathrm{n}_{\mathrm{s}}$ is the number of cells connected in series.

The reverse saturation current $\mathrm{I}_{\mathrm{rs}}$ varies according to the following equation:

$$
I_{r s}=I_{r r}\left[\frac{T}{T_{r}}\right]^{3} \exp \left(\frac{q E_{g}}{k A}\left[\frac{1}{T_{r}}-\frac{1}{T}\right]\right)
$$

where $I_{\mathrm{rr}}$ is the cell reverse saturation current at reference temperature; $T_{\mathrm{r}}$ is the reference temperature, 
$\mathrm{E}_{\mathrm{g}}$ is the band gap energy of the semiconductor used in the solar cell.

The light generated current $\mathrm{I}_{\mathrm{g}}$ varies according to the following equation:

$$
I_{g}=\left[I_{s c r}+K_{i}\left(T-T_{r}\right)\right] \frac{G}{100}
$$

where $\mathrm{I}_{\text {scr }}$ is the short circuit current at reference temperature; $\mathrm{K}_{\mathrm{i}}$ is the short circuit current temperature coefficient; $\mathrm{G}$ is the incident solar radiation in $\mathrm{mW} / \mathrm{cm}^{2}$.

\section{III.}

MAXIMUM POWER POINT TRACKING

The $\mathrm{P}-\mathrm{V}$ curve of a solar cell is a single peak curve. It implies that there is a particular operating point at which maximum power can be extracted from the solar cell. A maximum power point tracking controller is used for this. One among the most commonly used MPPT controllers is discussed here, ie. Incremental Conductance method. The flow chart of Incremental Conductance MPPT method is shown in the Fig. 2.

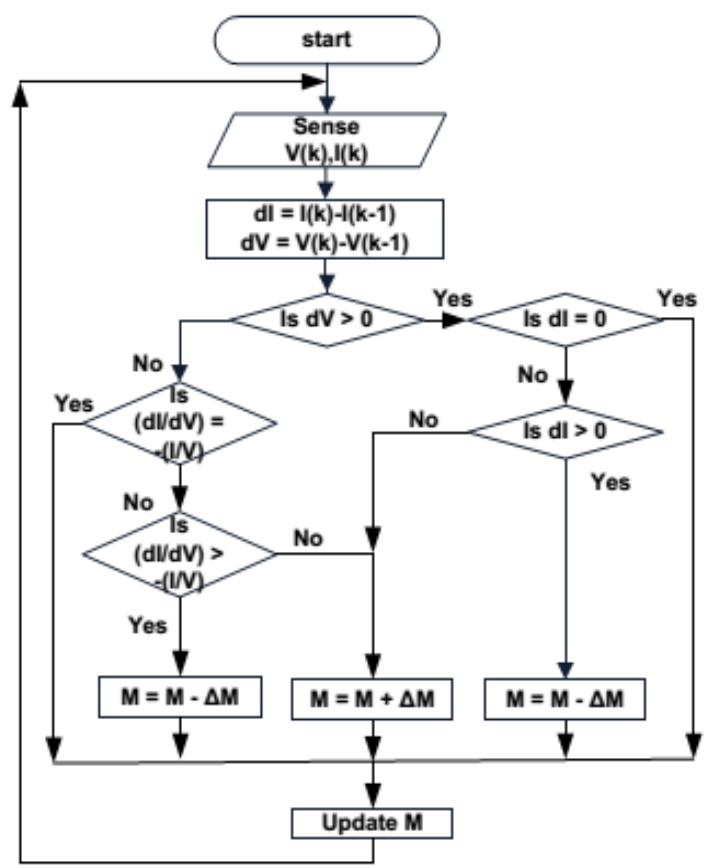

Fig. 2 Flow chart of Incremental Conductance MPPT

At maximum power point(MPP), $\mathrm{dI} / \mathrm{dV}=-\mathrm{I} / \mathrm{V}$. In Incremental conductance method the condition for MPP are checked and the reference voltage is varied accordingly.

IV. SINGLE PHASE FIVE LEVEL INVERTER

The single phase five level inverter topology considered here is shown in the Fig.3.

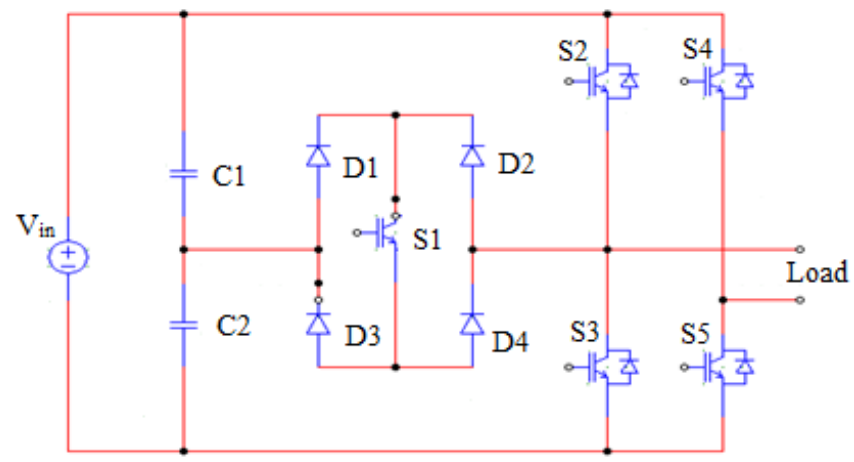

Fig. 3 Single phase five level inverter topology

The five level inverter topology consists of a full bridge inverter with an auxiliary circuit consisting of a diode bridge as shown in Fig. 3. 
The operating principle of the inverter is to generate five levels of voltage. ie, $V_{\text {in }}, V_{\text {in }} / 2,0,-V_{\text {in }} / 2,-V_{\text {in }}$. The half voltage level in the output voltage can be obtained by switching the auxiliary circuit switch properly.

The pulse width modulation scheme for the five level inverter is as follows: Two reference signals $\mathrm{V}_{\text {refl }}$ and $V_{\text {ref2 }}$ are compared with a high frequency carrier signal, $V_{\text {tri }}$ at the same time. If $V_{\text {refl }}$ exceeds the peak amplitude of the carrier, then $\mathrm{V}_{\text {ref2 }}$ will be compared with the carrier until it reaches zero. After that $\mathrm{V}_{\text {refl }}$ will be compared with $\mathrm{V}_{\text {tri. }}$. Fig. 4 shows the PWM law and the switching signals for the single phase five level inverter.

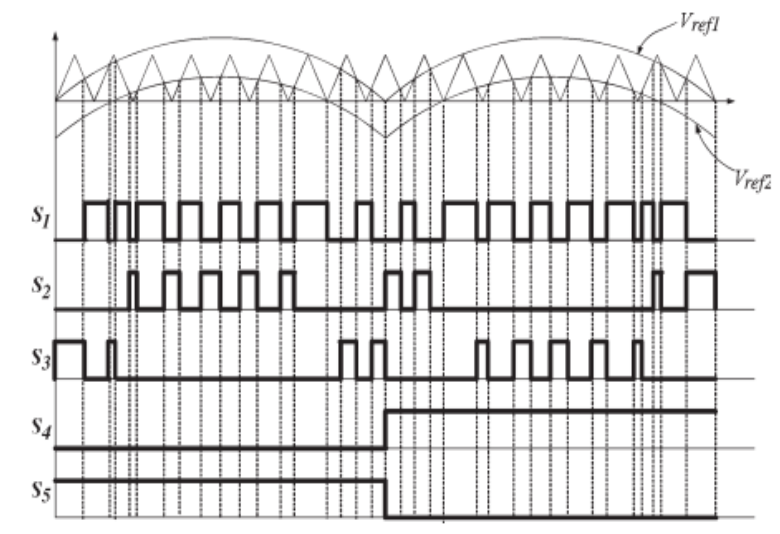

Fig. 4 PWM law and switching pattern for the single phase five level inverter

\begin{tabular}{|c|c|c|c|c|c|}
\hline $\mathbf{S 1}$ & $\mathbf{S 2}$ & $\mathbf{S 3}$ & $\mathbf{S 4}$ & $\mathbf{S 5}$ & $\mathbf{V}_{\mathrm{inv}}$ \\
\hline$O N$ & $O F F$ & $O F F$ & $O F F$ & $O N$ & $+\mathrm{V}_{\mathrm{pv}} / 2$ \\
\hline$O F F$ & $O N$ & $O F F$ & $O F F$ & $O N$ & $+\mathrm{V}_{\mathrm{pv}}$ \\
\hline \multirow{3}{*}{$O F F$} & $O F F$ & $O F F$ & $O N$ & $O N$ & \\
& $O r$ & $O r$ & $O r$ & $O r$ & 0 \\
& $O N$ & $O N$ & $O F F$ & $O F F$ & \\
\hline$O N$ & $O F F$ & $O F F$ & $O N$ & $O F F$ & $-\mathrm{V}_{\mathrm{pv}} / 2$ \\
\hline$O F F$ & $O F F$ & $O N$ & $O N$ & $O F F$ & $-\mathrm{V}_{\mathrm{pv}}$ \\
\hline
\end{tabular}

Table I Inverter output voltage during switches S1-S5 on and off

\section{SINGLE PHASE SEVEN LEVEL INVERTER}

The single phase seven level inverter topology considered here is shown in the Fig. 5. This topology was actually derived from the five level inverter discussed in section IV. It comprises of single phase conventional H-bridge inverter, two bidirectional switches and a capacitor voltage divider formed by $\mathrm{C} 1, \mathrm{C} 2$, and C3 as shown in Fig.5. This topology has got many advantages over other topologies like it requires only less number of power switches, power diodes and capacitors for the same number of voltage levels.

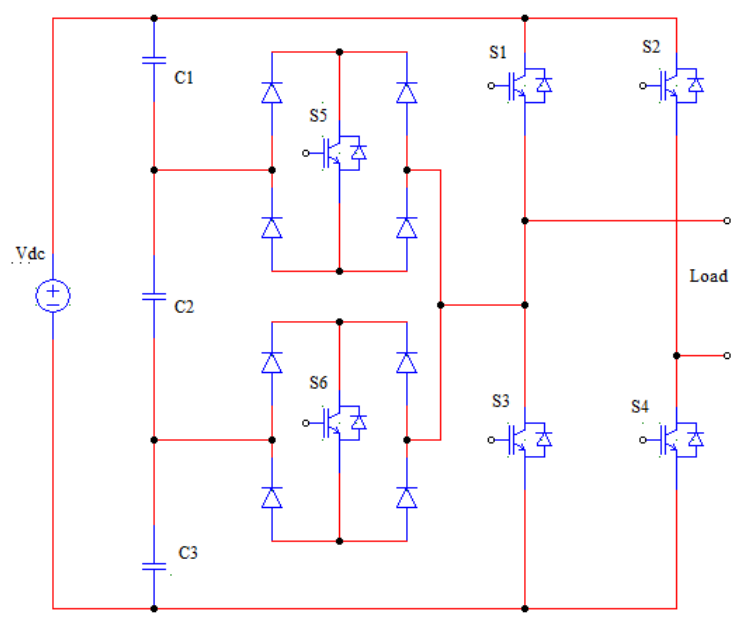

Fig. 5 Single phase seven level inverter topology

The operating principle of the inverter is to generate seven levels of voltage. ie, $V_{\text {in }}, V_{\text {in }} / 3,2 V_{\text {in }} / 3,0$, $\mathrm{V}_{\text {in }} / 3,-2 \mathrm{~V}_{\text {in }} / 3,-\mathrm{V}_{\text {in }}$. The intermediate voltage levels in the output voltage can be obtained by proper switching. 
The PWM for the seven level inverter requires three reference signals $\mathrm{V}_{\text {ref1 }}, \mathrm{V}_{\text {ref2, and }} \mathrm{V}_{\text {ref3 }}$. These three reference signals were compared with a carrier signal (Vcarrier). The reference signals had the same frequency and amplitude and were in phase with an offset value that was equivalent to the amplitude of the carrier signal. The reference signals were each compared with the carrier signal. If Vrefl had exceeded the peak amplitude of Vcarrier, Vref2 was compared with Vcarrier until it had exceeded the peak amplitude of Vcarrier. Then, onward, Vref3 would take charge and would be compared with Vcarrier until it reached zero. OnceVref3 had reached zero, Vref2 would be compared until it reached zero. Then, onward,Vref1 would be compared with Vcarrier. The switching pattern for the seven level inverter is shown in Fig.6.

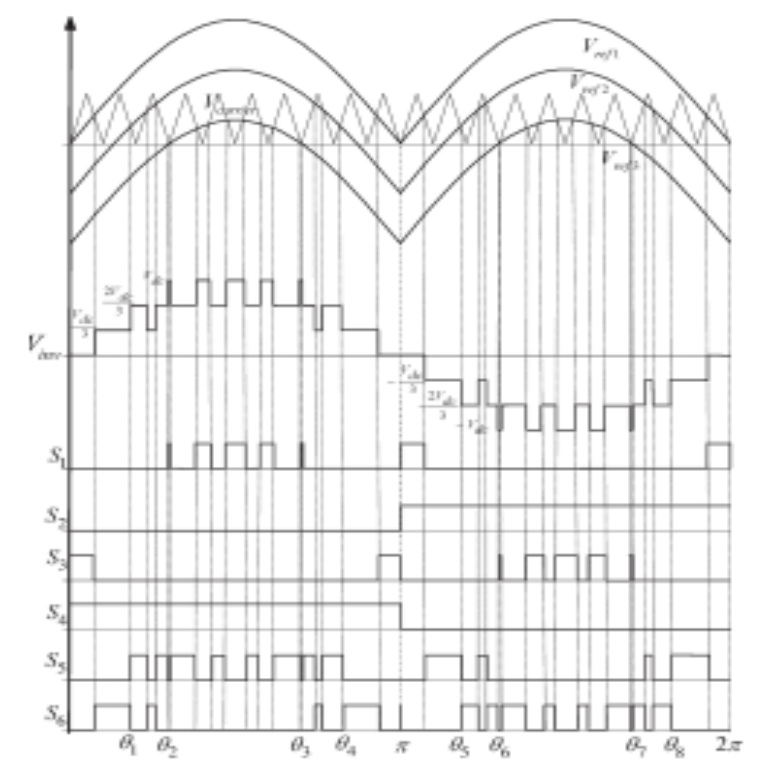

Fig.6 Switching pattern for the seven level inverter

Table II shows the output voltage level $\mathrm{V}_{\text {inv }}$ of the inverter during the switches S1-S6 on and off.

\begin{tabular}{|c|c|c|c|c|c|c|}
\hline S1 & S2 & S3 & S4 & S5 & S6 & $V_{\text {inv }}$ \\
\hline$O N$ & OFF & OFF & $O N$ & OFF & OFF & $\mathrm{V}_{\mathrm{dc}}$ \\
\hline OFF & OFF & OFF & $O N$ & $O N$ & OFF & $2 \mathrm{~V}_{\mathrm{dc}} / 3$ \\
\hline OFF & OFF & OFF & $O N$ & OFF & $O N$ & $\mathrm{~V}_{\mathrm{dc}} / 3$ \\
\hline OFF & OFF & $O N$ & $O N$ & OFF & OFF & 0 \\
\hline OFF & $O N$ & OFF & OFF & $O N$ & OFF & $-\mathrm{V}_{\mathrm{dc}} / 3$ \\
\hline OFF & $O N$ & OFF & OFF & OFF & $O N$ & $-2 \mathrm{~V}_{\mathrm{dc}} / 3$ \\
\hline OFF & $O N$ & $O N$ & OFF & OFF & OFF & $-\mathrm{V}_{\mathrm{dc}}$ \\
\hline
\end{tabular}

Table II Switching pattern for seven level inverter

\section{CONTROL SYSTEM FOR GRID CONNECTION OF PV MODULE}

Fig. 7 shows the block diagram of a grid connected PV system.

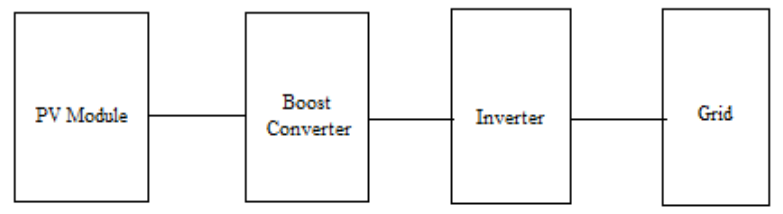

Fig.7 Block schematic of grid connected PV system

In a grid connected PV system PV module is coupled with a boost converter. The boost converter performs the Maximum power Point tracking and voltage amplification if necessary. The inverter handles output current regulation and DC bus voltage regulation. Also while grid interfacing it should be ensured that the power flow is from the PV module to the grid. For this the DC link voltage must be kept greater than the peak value of the grid voltage. Apart from this the control system should also ensure that the current injected 
into the grid is sinusoidal and is in phase with the grid voltage. ie, the power must be injected into the grid at unity power factor.

The block diagram for the control system is shown in the Fig. 8.

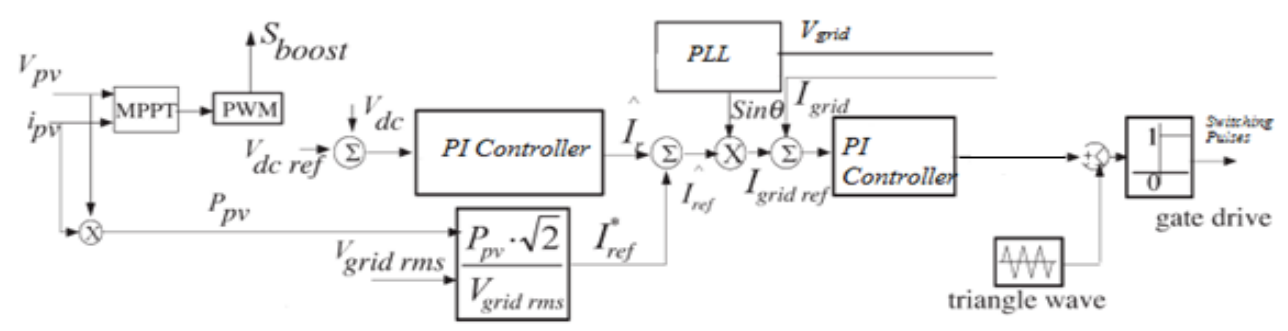

Fig.8 Control system for grid interfacing of PV system

The control system comprises an MPPT algorithm, a DC bus voltage controller, reference current generation and current controller. The two main tasks of control system are to maximize the energy transferred from PV modules to the grid and also to generate a sinusoidal current with minimum harmonic distortion.

Here Incremental conductance MPPT is used because it is more accurate compared to other methods. The incremental conductance algorithm was implemented in the DC-DC boost converter. The output of MPPT is the duty cycle function. As the duty cycle is varied the PV module output voltage will be varied which inturn varies the boost converter output. The DC link voltage $\mathrm{V}_{\mathrm{dc}}$ was controlled in the inverter. For this a PI controller is used. The DC link voltage is compared with the reference value and the error is fed into the PI controller, which subsequently tries to reduce the error. In this way $V_{\mathrm{dc}}$ can be maintained at a value greater than the peak value of grid voltage.

For delivering energy properly to the grid the frequency and phase of the inverter should be same as that of the grid voltage. Therefore a proper grid synchronization method is necessary. For this a Phase Locked Loop (PLL) is used in the control system so as to generate a reference current which is in phase with the grid voltage. The current injected into the grid ie, $\mathrm{I}_{\text {grid }}$ is compared with the reference grid current ie, $\mathrm{I}_{\text {grid ref }}$ and the error is fed into a PI current controller. The output of the PI controller is compared with a triangular signal so as to obtain switching pulses to the inverter.

\section{A. Simulation Results}

\section{SIMULATION AND EXPERIMENTAL RESUlTS}

In order to verify whether the five level inverter can be practically used in a grid connected system simulations are performed using MATLAB/SIMULINK.

The PV module is modelled for SWG245MONO whose datasheet parameters are given in Fig.7

\begin{tabular}{ccc}
\hline & \multicolumn{2}{c}{ Datasheet Parameters for SW245MONO } \\
\hline Irradiance & $1000 \mathrm{~W} / \mathrm{m}^{2}$ & $800 \mathrm{~W} / \mathrm{m}^{2}$ \\
$\boldsymbol{I} \boldsymbol{m p p}$ & $7.96 \mathrm{~A}$ & $6.37 \mathrm{~A}$ \\
$\boldsymbol{V} \boldsymbol{m p p}$ & $30.8 \mathrm{~V}$ & $28.1 \mathrm{~V}$ \\
Pmax & $245 \mathrm{~W}$ & $179 \mathrm{~W}$ \\
$\boldsymbol{I} \boldsymbol{s c}$ & $8.25 \mathrm{~A}$ & $6.65 \mathrm{~A}$ \\
$\boldsymbol{V} \boldsymbol{o c}$ & $37.7 \mathrm{~V}$ & $34.4 \mathrm{~V}$ \\
$\boldsymbol{K} \boldsymbol{v}$ & $-0.33 \mathrm{~V} / \mathrm{K}$ & $-0.33 \mathrm{~V} / \mathrm{K}$ \\
$\boldsymbol{K} \boldsymbol{i}$ & $0.042 \mathrm{~A} / \mathrm{K}$ & $0.042 \mathrm{~A} / \mathrm{K}$ \\
$\mathbf{N s}$ & 60 & 60 \\
\hline
\end{tabular}

Fig.9 Data sheet parameters of SWG245MONO

The PV module is then coupled with a boost converter. The Incremental conductance MPPT was implemented using SIMULINK blocks in the boost converter. The control to the inverter is given according to the control system shown in Fig.6. Here the grid voltage was set at $240 \mathrm{~V}_{\mathrm{rms}}, 50 \mathrm{~Hz}$. A step up power transformer is used to interface the inverter output to the grid. The primary of the step up transformer was set at $120 \mathrm{~V}_{\mathrm{rms}}$. Also a coupling inductance $\mathrm{Lf}$ is used to filter the inverter output. The DC link voltage reference was set at $280 \mathrm{~V}$. 


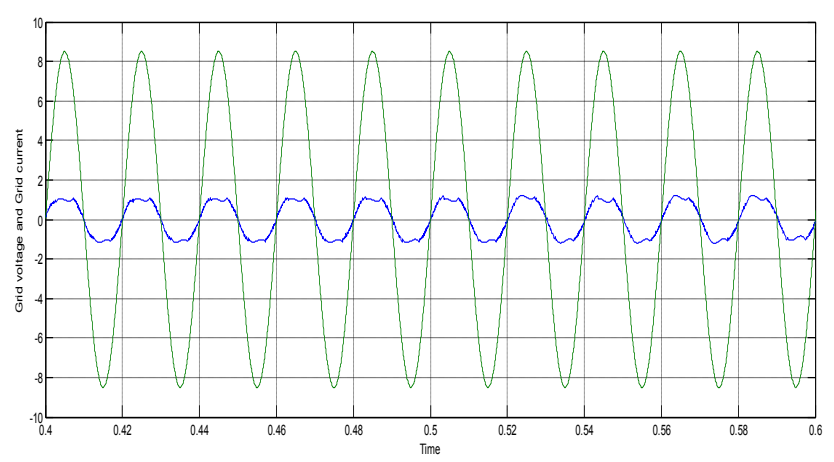

Fig.10 Grid voltage and Grid current using conventional H-bridge inverter

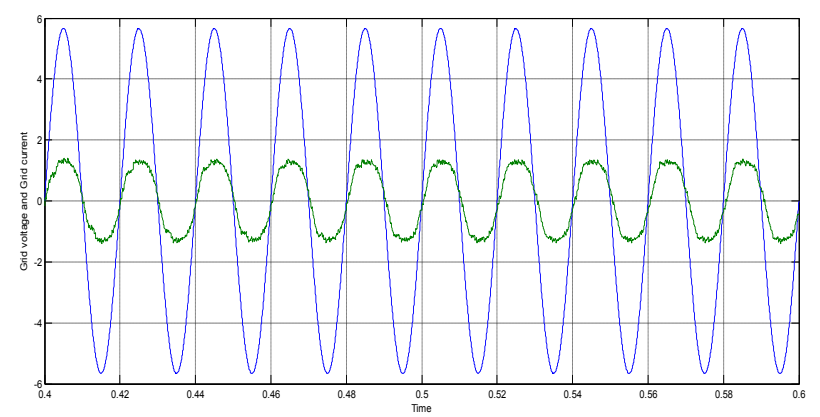

Fig.11 Grid voltage and Grid current using five level inverter

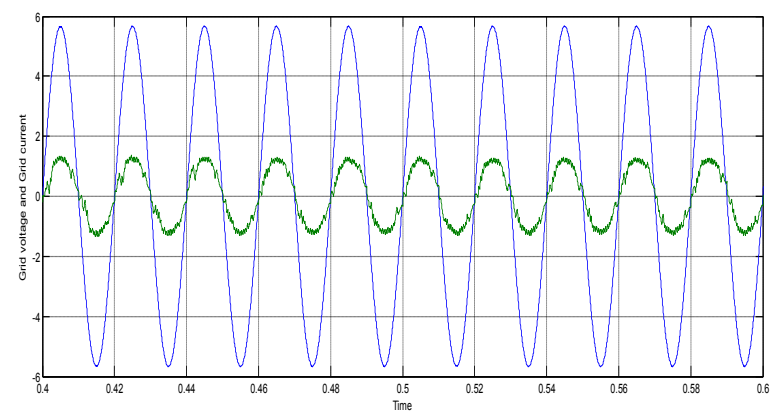

Fig. 12 Grid voltage and Grid current using seven level inverter

Also in order to ensure that the multilevel inverters offer less THD compared to conventional H-bridge inverter, the FFT analysis of the simulation results were carried out in MATLAB. Fig.13 shows a comparison of THD levels of the current injected into the grid using the conventional H-bridge inverter and the multilevel inverter topologies discussed in this paper. While using conventional H-bridge inverter the THD level was around $11 \%$ and it was reduced to $7.8 \%$ by using the five level inverter. Again while seven level inverter was used THD was inturn reduced to $5.38 \%$.

VIII. CONCLUSION

In these days of fast depleting conventional energy sources, photovoltaic systems are a very good alternate. Here a PV module is modelled using mathematical equations. Also a grid connected photovoltaic system is simulated in MATLAB/SIMULINK. From the simulation results it was observed that the control algorithm works well with changing atmospheric conditions. Using multilevel inverters in such grid connected PV system considerably reduces the THD level of the current injected into the grid. 


\section{REFERENCES}

[1] K.H. Hussein, 1. Muta ,1. Hoshino ,M. Osakada: 'Maximum Photovoltaic Power Tracking: an algorithm for rapidly changing atmospheric conditions', IEEE Proc Generation, Transmission, Distribution, Vol.142, No.1, January 1995.

[2] J. Rodriguez, J.-S. Lai, and F. Z. Peng, “Multicarrier PWM strategies for multilevel inverters,'”IEEE Trans. Ind. Electron., vol. 49, no. 4, pp. 724-738, Aug. 2002.

[3] Trishan Esram, Student Member, IEEE, and Patrick L. Chapman, Senior Member, IEEE.: 'Comparison of Photovoltaic Array Maximum Power Point Tracking Techniques', IEEE transactions on Energy Conversion, vol. 22, no. 2, June 2007.

[4] S. Jain and V. Agarwal, 'Comparison of the performance of maximum power point tracking schemes applied to single-stage gridconnected photovoltaic systems’, IET Electr. Power Appl., 2007, 1, (5), pp. $753-762$

[5] Jeyraj Selvaraj and Nasrudin A. Rahim,Senior Member, IEEE, 'Multilevel Inverter For Grid-Connected PV System Employing Digital PI Controller', IEEE transactions on Industrial Electronics, Vol. 56, No. 1, January 2009

[6] Nasrudin A. Rahim,Senior Member, IEEE, Krismadinata Chaniago,Student Member, IEEE, and Jeyraj Selvaraj , 'Single-Phase Seven-Level Grid-Connected Inverter for Photovoltaic System', IEEE Transactions on Industrial Electronics, Vol. 58, No. 6, June 2011 